\title{
The use of M-Learning in Teaching English for Civil Engineering Students
}

Submitted: Feb 25, 2020

Accepted: Apr 10, 2020

Published: Apr 10, 2020

\author{
Dharmawati \\ Universitas Harapan Medan \\ Medan, North Sumatera \\ Dharmawati66@yahoo.com
}

\begin{abstract}
This research had aimed to describe the use of M-Learning in teaching English for Civil Engineering students at Harapan University of Medan. M-learning as Digital teaching materials were made based on the students need which consist of learning materials. M-learning as Digital teaching materials can be used by lecturer to create more interesting learning materials, by adding videos and animations. The use of M-learning as digital teaching materials was examined based on concepts understanding and students' response. The subject of this research was 25 students of engineering students. The concepts of understanding were measured by exam test. The students' response was measured based on Likert-scales. The data analysis used was a descriptive statistic. The method of this research was quantitative method. Waterfall model was used in designing M-learning material. The results of this research is the score of students' conceptual understanding $\mathrm{x}=(85 \pm 8)$ and students' response can be categorized very good (percentage of effectiveness are $85 \%$ ). The results showed that the use of Mlearning as digital teaching materials are effective to use in teaching English for civil engineering students at Harapan University of Medan.
\end{abstract}

Keywords - ICT, M-Learning, Civil Engineering Students

\section{INTRODUCTION}

Information and communication technology (ICT) is developing so rapidly to meet the needs of human life in all aspects such as in politics, economic, culture, religion and education. (Khan M S, 2015) says that information communication technology (ICT) refers to technologies that provide access to information through communications, he added that ICT stands for information and communications technology. The use of ICT in the field of education aims to make teaching learning more effective and efficient for example using it as a learning media, digital teaching materials, teaching learning materials to students online etc. The use of technology in learning process support the varieties of teaching learning media that can be chosen in order to use in teaching learning process (Dharmawati, 2017). Computer-based learning is a learning method that uses computers as the main media to deliver learning content or knowledge in a field of science (Riza \& Ade, 2019)
The impact of the development of ICTs is also followed by the rapid development of smartphones so that almost every month new-generation smartphones always emerge. Recently smartphones have become very common in everyday lives, including students so that their existence can disrupt the learning process especially English in conventional classes. Lecturers should use ICTs including smartphones in teaching English learning process because the technology is very useful in learning.

English learning for civil engineering students requires media that can explore material to present both facts, concepts, processes, and metacognitive to students especially for engineering students. Generally, English learning in higher education like university is less attractive for student especially civil engineering students, they pay more attention to productive subjects. One of the standard competencies of graduates in higher education must be fullfil by the institution. The second perspective to analyze the competence is Peraturan Pemerintah 
(Government Regulation) No. 19 of 2005. The regulation stated that the graduate competence in studying language as shown in article 25 , verse 3 and 4 (Perpu, 2005):

Verse 3

Kompetensi lulusan untuk mata pelajaran bahasa menekankan pada kemampuan membaca dan menulis yang sesuai dengan jenjang pendidikan (the graduate competence for language lessons emphasize the ability to read and write based on the level of education)

Verse 4

Kompetensi lulusan sebagaimana dimaksud pada ayat (1) dan (2) mencakup sikap, pengetahuan, dan keterampilan (the graduate competence as in verse (1) and (2) include of behaviour, knowledge and skills)

After reading this regulation, the writer found two key words/phrases, namely (1) Language lesson ability to read and write, (2) The graduate competence includes of behavior, knowledge and skills. The key words/phrases mean that the civil engineering student competence must be suitable with the government regulation. However the government regulation does not specifically formulate the competence to be achieved at the end of English lesson in teaching civil engineering students. To meet these standards, lecturer can apply various learning methods and approaches, and one effort to synergize English learning with the productive fields of Multimedia majors is to utilize information and communication technology (ICT).

Therefore, this study aims to describe the use of M-learning as teaching materials in learning English for civil engineering students.

\section{Literature REVIEW}

1. ICT

ICT stands for Information and Communication Technology. According to khan (2015) information communication technology (ICT) refers to technologies that provide access to information through communications. ICT is a tool of global educational development. One of the uses of computers in learning activities is to become a learning media (Rika \& Henny, 2019). Smartphone is one of the ICT products that gradually penetrates into students' daily activities and becomes part of their lives. A smartphone is also called by a smartphone with an integrated computer and other features not originally associated with telephones such as an operating system, web browsing, and the ability to run software applications. Smartphones can definitely be taken as to enhance education
(Almunawar, 2015), as many people use smartphones to gain or collect information and learn knowledge from the Internet. With this development, for educators, mobile technologies give rooms and spaces for exploring new pedagogies by creating lesson plans in the light of the potential of new Apps and software (Jati, 2018). The use of smartphones that are growing rapidly, it allows lecturer to package paper-based teaching materials into digital teaching materials so that they can use smartphones become effective learning facilities.

\section{M-Learning}

M-learning as Digital teaching materials can be used by lecturer to create more interesting learning materials, by adding videos and animations. (Quinn, 2010) states that the intersection of mobile computing and e-learning: accessible resources wherever you are, strong search capabilities, rich interaction, powerful support for effective learning, and performance-based assessment. E-Learning can be accessed independently of location in time or space.

The Mobile learning (M-learning) as a form of elearning is a new trend where the education has outgrown the physical constraints of the classrooms process and acquired mobility both lecturer and students. By using M-learning Students access information to learn their lecturing materials whenever and wherever they want, and institutions that provides such advanced technological terrains is rising in number day by day. Digital teaching materials allow students to do activities to learn and comprehend the materials, direction, and various learning information and that is not limited to space and time.

The M-learning material that has been created and is being created provides on the digital study material from all subjects they learnt especially English subject. Digital teaching materials are also able to train students to learn independently from various sources provided. That's way the lecturer should design the teaching material interactively and easy to used by the students. So, they will be motivated to learn English.

3. Civil Engineering Students

Civil engineering is one of majoring at Harapan University of Medan. The students of civil engineering are responsible for designing, constructing, and maintaining the built environment. English is also taught in this major for two semesters, they are semester one and two. In the first semester, they study English in general and in the second semester, they study technical English. In teaching English for civil engineering students, the lecturer 
gives them the teaching materials which can be accessed by smartphone. So every students can learn their English materials such as grammar, and reading every where and time by their smartphone effectively.

\section{Proposed Method}

The method of this study used quantitative method with pre-experiment design. Manipulation variables in this study are learning to use Android-based digital teaching materials while the dependent variable is mastery of English subject mastery and student responses in learning using the teaching learning materials. Data collection techniques use written tests and questionnaires. The procedures of this research used waterfall model. This model is very popular to used, because software development life cycle are usually based on the classical waterfall model. The waterfall model are shown in the below figure.

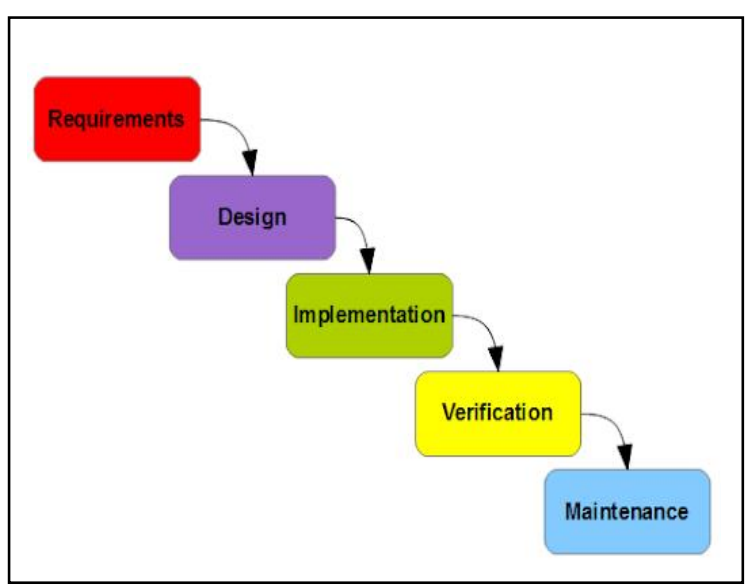

Fig. 1 Waterfall Model

Based on figure one first the lecture arranged some requirements for the need of this research. Second design, in this step M-learning for teaching material was designed. The third implementation is a part to apply m-learning for students. Forth is verification, and the last was maintaice the application of m-learning material.

The procedure for designing android-based digital teaching materials in this study were: 1) preparing material for teaching material for reading (in the form of text, images, audio) ; 2) designing leaning material which had been arranged by the lecturer; 3) apply the instructional material that has been designed into the Android application worksheet 4) files for Android-based digital teaching materials are ready to be used in teaching learning process. The procedure of designing m-learning for English material for civil engineering students is presented in Figure 1 as follows:

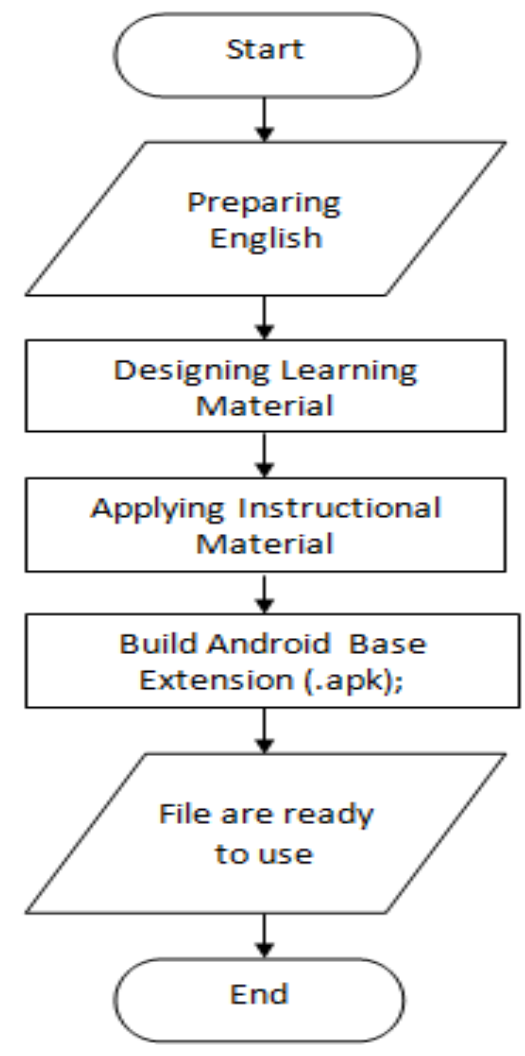

Fig 2. Procedure of Designing Digital Teaching Materials

\section{RESULT AND DISCUSSION}

M-learning as digital teaching material is one of raising learning resources, which contains learning messages from the lecturer to students and it can be used for the benefit of teaching learning process. Android-based digital teaching learning materials are teaching materials which students learned that are packaged in digital form for teaching learning in the classroom.

The teaching material files are for civil engineering students then distributed to students to be installed on students' Android-based smartphones. So the materials installed were used for lecturer and students in teaching learning process. Some examples of slides from teaching reading materials about 'crane' and the exercises from crane material can be presented as shown in Figure 2 as follows: 


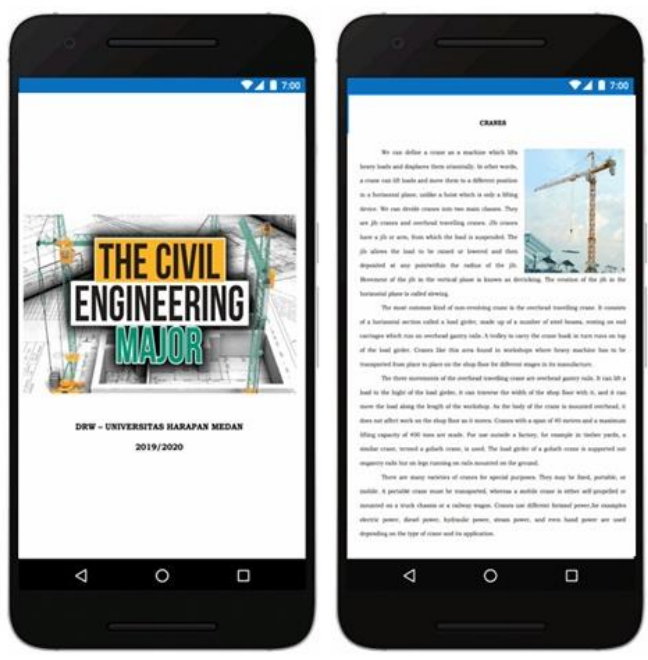

Fig 3. Reading Teaching Materials

Based on figure 2, it can be seen that some slides from teaching reading materials which are given for the civil engineering students consisting of civil engineering items. Civil engineering students learn English fo specific purpose.
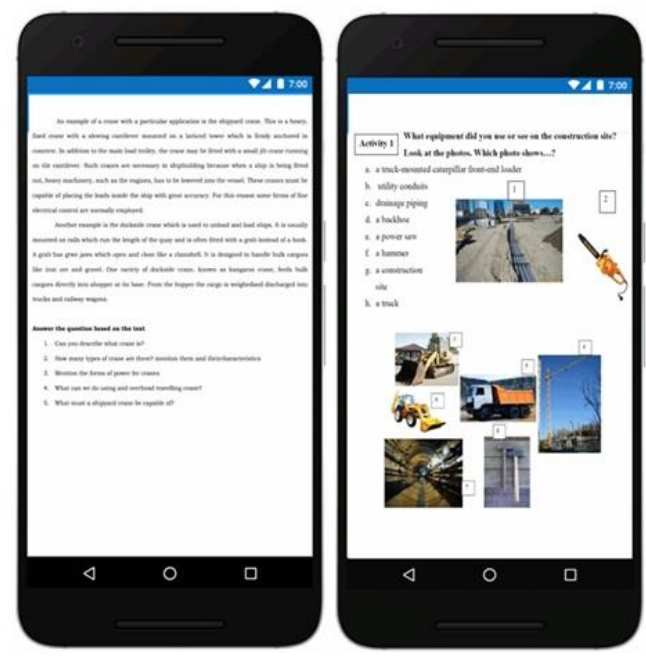

Fig 4. Exercises

Based on figure 3, it can be seen that some slides from exercises from reading text. In learning reading comprehension, students were asked by the lecturer to read the text and the lecturer corrected studenent's reading. After reading the text, they were given some exercises. While doing the exercises, they analyze the text together to comprehend it. This materials designed based on multimedia composing of text, audio, images and video. The teaching material can be a supporter of learning English for reading skill.
After using and learning materials included in teaching learning material, students are given a test to find out how students mastery of reading material text.

The effectiveness of the use of teaching materials in term of students' mastery in learning reading is very important for students because it can be an indicator that students have fully understood what they have been learned. Mastery of reading text can also help students in solving problems in their everyday life. The mastery in reading text obtained by the students can be seen in figure 3 below.

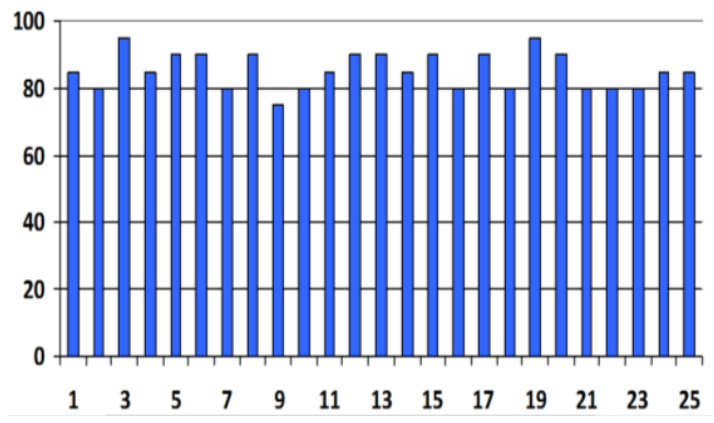

Fig 5. Students' Mastery in Reading Text

Based on figure 5, it can be concluded that the students have score above the minimum completeness criteria, which is is $\geq 75$. In addition, classically, the average student score is $x=(85 \pm 8)$, which means greater than the classical minimum completeness score. Based on these results, the use of M-learning in teaching English for civil engineering students is effective in terms of students' mastery of learning reading score.

The use of m-learning in teaching English for civil engineering students have the potential to get a good motivation from students because it makes it easier for students to use that application in learning and facilitate students in accessing the teaching materials that the lecturer has prepared. The application files that are prepared are easy to install and also use by having smartphones. It consists of interesting materials by applying video and animation. The files installed on smartphones can present multimedia so that it has the potential to be fun and make it easier for civil engineering students in multimedia in understanding English teaching materials.

Based on the students' response, it can be seen that the use of M-learning in teaching English materials is effectively used in learning English for civil engineering students. And students were motivated to learn it. 


\section{Conclusion ANd Suggestion}

The use of M-learning teaching materials supported the mastery of the English subject by having scores of all students $\geq 75$ and the average score of students $(84 \pm 8)$. These results indicate that the use of M-learning teaching materials can effectively support the mastery of students' English subject. The students' responses are all in a good mode with an effectiveness percentage of $85 \%$ that far exceeds that required at least 70 . The results can be concluded that the use of M-learning in teaching English materials can be more flexible because process is very important. Students can use their smartphones not only for browsing social media but also learning their materials in university. Lecturers have to improve their knowledge in creating digital teaching materials.

\section{ACKNOWLEDGMENT}

The writer thanks goes to Mr. Abdul Jabbar Lubis, ST, M.Kom as the dean of Universitas Harapan Medan who has supported and motivated this research. Thanks also to colleagues, and kind students who have helped complete this research, so that this research can be completed on time.

\section{REFERENCES}

Almunawar, M. N., Anshari, M., Susanto, H., \& Chen, C. K. (2015). Revealing customer behavior on smartphones. International Journal of Asian Business and Information Management, 6(2), 33-49

Darmawan, Deni. (2014). Pengembangan ELearning Teori dan Desain. PT Remaja Rosdakarya. Bandung.

Davies, Z. (2015). Definition of: Smartphone. USA: PCMag Digital Group.

Dimas A, Omar P \& Tri S. (2019). Disaster Information on Mobile Applications in Indonesia Using Sequential Search AlgorithmsBased On Android. SinkrOn
(Jurnal \& Penelitian Teknik Informatika), 4 (1), 78-82.

Dharmawati. (2017). Penggunaan Media E-Learning Berbasis Edmodo Dalam Pembelajaran English for Business. Query: Jurnal Sistem Informasi. Vo. 01 No. 1.

Jati Gumawang. (2018). The Use Of Smartphone Applications In English Language Teaching And Learning. Jurnal Sosioteknologi. Vol. 17 No.1, hal 144-153.

Khan M S, Khan I, Din S, Ismail H M, Rafid K, et al. (2015). The Impacts of ICT on the Students' Performance: A Review of Access to Information. Res Human Soc Sci 1: 22245766.

Mohammad Mahdi M. (2018). The Use of Mobile Technology in Learning English Language. Theory and Practice in Language Studies, Vol. 8, No. 11, 1456-1468

Paltridge, B \& Starfield, S. (2013). The Handbook of English for Specific Purposes. Boston: John Wiley \& Sons Inc.

Perpu. (2005). Peraturan Pemerintah Nomor 19: Standar Nasional Pendidikan. Jakarta: Departemen Pendidikan Nasional.

Quinn, N., Clark. (2010). M-Learning: An Introduction to Mobile Learning. Orlando: Firlandia.

Rika, D \& Henny, D. (2019). Interactive Animation Design of Hijaiyah Letters in Early Age Children at Al-Hidayah Kindergarten Bekasi. SinkrOn (Jurnal \& Penelitian Teknik Informatika), 3 (2), 89-98

Riza M M \& Ade S B. (2019). Development of Belajar Astronomi:an Astronomy Learning Application for Kids. SinkrOn SinkrOn (Jurnal \& Penelitian Teknik Informatika), 3 (2), 79-88.

Tayebinik, M, Puteh, M. (2012). Mobile Learning To Support Teaching English As A Second Language. Journal of Education and Practice. Vol 3, No 7, 56-62. 